УДК 33

DOI $10.21661 / \mathrm{r}-472068$

\title{
P.O. Рашев
}

\section{ПРОБЛЕМЫ ПОСТУПЛЕНИЯ ППИ. АНАЛИЗ ПОСТУПЛЕНИЯ ВХОДЯЩИХ ИНОСТРАННЫХ ИНВЕСТИЦИЙ В РФ В ПЕРИОД 2009-2017 ГГ.}

Аннотация: прямые иностранные инвестиции оказывают существенное влияние на развитие экономики РФ. Необходимо уделить больше внимания для привлечения зарубежных инвестищий в Россию и снять все сложности на пути их поступления. Инвесторы имеют ряд проблем с реализацией инвестищий в нашей стране, поэтому сдерживаются инвестиционные проиессы и эта деятельность в целом. Привлечение в экономику России ППИ имеет ряд преимуществ. В статье приведен анализ входящих иностранных инвестиций в РФ за 2009-2017 г2. Озвучены основные проблемы и рекомендации.

Ключевые слова: прямые иностранные инвестиции, экономика, инвестиции, Центральный Банк, Росстат, статистика.

\section{R.O. Rashev}

\section{PROBLEMS OF PPI ADMISSION. ANALYSIS OF INCOMING FOREIGN INVESTMENTS IN RUSSIA IN THE PERIOD 2009-2017}

Abstract: foreign direct investment has a significant impact on the development of the Russian economy. It is necessary to pay more attention to attract foreign investment in Russia and remove all the difficulties on the way of their receipt. Investors have many problems with the implementation of investments in our country, so investment processes and this activity in general are constrained. Attracting PPI to the Russian economy has many advantages. Analysis of incoming foreign investments in Russia for 2009-2017 is given in the article. Main problems and recommendations are represented. 
Keywords: foreign direct investment, economy, investment, Central Bank, Russia, Rosstat, statistics.

Прямые иностранные инвестиции (далее - ПИИ) оказывают существенное влияние на развитие экономики РФ. Они способствуют, посредству их реализации, увеличению экономического роста, появлению инновационных проектов, увеличению объема производства продуктов и дохода, роста государственного бюджета. Исходя из этого, важно уделить больше внимания для привлечения зарубежных инвестиций в Россию и снять все сложности на пути их поступления. Данная тематика работы актуальна, в связи с тем, что инвесторы имеют ряд проблем с реализацией инвестиций в нашей стране, поэтому сдерживаются инвестиционные процессы и эта деятельность в целом.

Какие плюсы имеет экономика России, при привлечении ПИИ?

Во-первых, это привлечение дополнительного капитала, технологий. Вовторых, это увеличение роста ВВП, модернизация производства. В-третьих, рост конкурентоспособности продукции российских марок. В-четвертых - ускорение процесса диверсификации экспорта. В-пятых - снижение уровня аварийности на промышленных объектов [1, с. 102].

Для осознания всей проблематики и раскрытия темы необходимо привести статистические данные.

Проведя анализ объема ПИИ в Российской Федерации с 2007 года по 2014 год можно отметить, что наибольший объем ПИИ наблюдался в 2008 году в размере 74783 млн долл. США. Статистические данные представлены в таблице 1: 
Таблица 1

Данные по прямым иностранным инвестициям публикуются

Банком России в разделе «Статистика» (подраздел «Статистика внешнего сектора»), Росстатом в [I.6, I.18], UNCTAD, World Bank с 2009-2014 гг.

\begin{tabular}{|c|c|c|c|c|c|}
\hline Год & Показатель & $\begin{array}{c}\text { Объем прямых } \\
\text { инвестиций, } \\
\text { поступивших } \\
\text { от } \\
\text { иностранных } \\
\text { инвесторов } \\
\text { [I.6, I.18], gks.ru }\end{array}$ & $\begin{array}{c}\text { Прямые } \\
\text { инвестиции в } \\
\text { РФ, сальдо } \\
\text { операций } \\
\text { платежного } \\
\text { баланса [ЦБ } \\
\text { РФ] }\end{array}$ & $\begin{array}{l}\text { Inward foreign } \\
\text { direct } \\
\text { investment } \\
\text { flows } \\
\text { [UNCTADstat] }\end{array}$ & $\begin{array}{c}\text { Foreign } \\
\text { direct } \\
\text { investment, } \\
\text { net } \\
\text { inflows } \\
\text { (BoP) } \\
\text { [WB, World } \\
\text { Databank] }\end{array}$ \\
\hline 2009 & Всего & 15,91 & 36,583 & 36,5 & 36,5 \\
\hline \multirow[t]{6}{*}{2010} & Всего & 13,81 & 43,168 & 43,29 & 43,29 \\
\hline & $\begin{array}{l}\text { Из них: } \\
\text { взносы в } \\
\text { капитал }\end{array}$ & 7,7 & - & - & - \\
\hline & $\begin{array}{l}\text { кредиты, } \\
\text { полученные } \\
\text { от зарубежных } \\
\text { владельцев } \\
\text { организаций }\end{array}$ & 4,61 & - & - & - \\
\hline & $\begin{array}{l}\text { прочие } \\
\text { прямые } \\
\text { инвестиции }\end{array}$ & 1,5 & - & - & - \\
\hline & $\begin{array}{l}\text { Банковский } \\
\text { сектор }\end{array}$ & - & 5,164 & - & - \\
\hline & $\begin{array}{l}\text { Прочие } \\
\text { секторы }\end{array}$ & - & 38,004 & - & - \\
\hline 2011 & Всего & 18,42 & 55,084 & 52,88 & 52,88 \\
\hline 2012 & Всего & 18,67 & 50,588 & 50,59 & 50,59 \\
\hline 2013 & Всего & 26,12 & 69,218 & 69,22 & 69,22 \\
\hline 2014 & Всего & 22,857 & 22,857 & 20,96 & 22,89 \\
\hline
\end{tabular}

Рассматривая динамику поступления прямых инвестиций от иностранных инвесторов в 2010-2014 гг., можно сделать следующий вывод: в 2014 году приток ПИИ уменьшился, несмотря на положительную динамику данного процесса с 2010 года [2, с. 19].

В 2009 году ситуация в корне поменялась, и последовал резкий спад, что привело к снижению объема ПИИ. Так в 2009 году объем ПИИ составил 36583 млн долл. США, что на 48,9\% меньше по сравнению с 2008 годом. Однако 
в последующие годы ПИИ постепенно увеличивались. В 2010-2011 гг. их объем увеличился на 50,6\% по отношению к 2009 году, а в 2013 году вырос на 36,8\% по сравнению с предыдущим годом и составил 69219 млн долл. США. В 2014 году последовало резкое снижение ПИИ. Объем прямых инвестиций составил всего 20958 млн долл. США, что на 30,3\% меньше по сравнению с предыдущим годом. С 2014 г. Росстат не публикует данные по иностранным инвестициям.

Во втором полугодии 2014 года об оттоке прямых иностранных инвестиций сообщил Банк России. Это произошло впервые после серьезного экономического спада в 2009 году. В 2014 году зарубежные инвестиции сократился до 22 млрд долларов США, что явилось рекордно низким уровнем с 2006 года. ПИИ в Россию в 2015 году упали до 6,853 млрд долларов США, а в 2016 г. наблюдается резкий рост до 32976 млрд

По данным Центрального Банка России, по состоянию на начало 2015 г., размер входящих прямых инвестиций, включая «не распределено (включая конфиденциальные данные)» составил 290,038 млрд долларов США., из них исключая «не распределено» 287,5 млрд долларов США.

Участие в капитале по ПИИ (входящие на нетто основе) составили: 235,6 млрд долларов США включая «не распределено», и исключая «не распределено» 214 млрд долларов США [3, с. 54].

Входящие прямые инвестиции по состоянию на начало 2016 года составили: по отчетным данным, включая «не распределено (включая конфиденциальные данные)» 262,7 млрд долларов США; исключая «не распределено» 260,6 млрд долларов США.

Участие в капитале по ПИИ (входящие на нетто основе) составили: 206,9 млрд долларов США включая «не распределено», и исключая «не распределено» 197,8 млрд долларов США.

Входящие прямые инвестиции по состоянию на начало 2017 года составили: по отчетным данным, включая «не распределено (включая конфиденциальные 
данные)» 377,9 млрд долларов США; исключая «не распределено» 375,3 млрд долларов США.

Участие в капитале по ПИИ (входящие на нетто основе) составили: 319,4 млрд долларов США включая «не распределено», и исключая «не распределено» 308,5 млрд долларов США. Данные представлены в таблице 2:

Таблица 2

Входящие прямые инвестиции в период с 2015-2017 гг.

в млрд долларов США

\begin{tabular}{|l|c|c|c|c|}
\hline \multicolumn{1}{|c|}{ Показатели } & 2015 & 2016 & 2017 & $\begin{array}{c}\text { Изменение } \\
\text { размера } \\
\text { инвестиций } \\
\text { за 3 года }\end{array}$ \\
\hline $\begin{array}{l}\text { Входящие прямые инвестиции, } \\
\text { включая «не распределено (включая } \\
\text { конфиденциальные данные)» }\end{array}$ & 290,038 & 262,7 & 377,9 & 87,862 \\
\hline $\begin{array}{l}\text { Входящие прямые инвестиции, ис- } \\
\text { ключая «не распределено» }\end{array}$ & 287,5 & 260,6 & 375,3 & 87,8 \\
\hline $\begin{array}{l}\text { Участие в капитале по ПИИ (входя- } \\
\text { щие на нетто основе) включая «не } \\
\text { распределено», }\end{array}$ & 235,6 & 206,9 & 319,4 & 83,8 \\
\hline $\begin{array}{l}\text { Участие в капитале по ПИИ (входя- } \\
\text { щие на нетто основе), исключая «не } \\
\text { распределено» }\end{array}$ & 214 & 197,8 & 308,5 & 94,5 \\
\hline
\end{tabular}

Прямые иностранные инвестиции в Россию в конце 2017 г. сократились.

По данным ЦБ, чистый приток снизился на 14,3\% - с 32,5 до 27,9 млрд долларов США [4, с. 99].

Хотя по итогам 2016 г. был зафиксирован рост ПИИ в 4,7 раза.

В том числе отмечается уменьшение в прошлом году:

- притока иностранных инвестиций в новые акции - с 18,5 до 9,7 млрд долларов США (почти в 2 раза);

- реинвестирования доходов - до 15,8 млрд долларов США (-8,2\%).

ПИИ через долговые инструменты выросли на 2,4 млрд долларов США - после снижения в 2016 г. на 3,2 млрд долларов США. 
Сальдо прямых инвестиций из России за рубеж в 2017 г. увеличилось до 38,6 млрд долларов США - в сравнении с 22,3 млрд США в 2016 г. и 22,1 млрд США в 2015 г.

Главным образом, данный рост был обеспечен вложениями резидентов РФ в новые акции зарубежных компаний.

Их объем возрос на 22,5 млрд долларов США [5, с. 39].

Это - в 2,6 раз больше, чем по итогам 2016 г. (8,7 млрд долларов США).

В целом, в 2017 г. наблюдался значительный приток иностранных инвестиций в Россию из оффшорных юрисдикций.

Итак, исходя из анализа статистических данных официальных структур РФ, выделим основные тенденции, проблемы и возможные рекомендации.

Система преференций и стимулов для иностранных инвесторов, существующая в России в целом отвечает подходу к ПИИ, характерному для мировой практики. Эти инструменты в пределах компетенций региональных и местных властей устанавливают льготный режим вхождения, присутствия иностранных инвестиций на региональных рынках и выхода из них. В качестве дополнительных средств регулирования во многих приграничных регионах РФ разработано собственное региональное и местное законодательство, также использующее практически все указанные выше группы инструментов поддержки и ограничений $[6$, с. 66].

Тем не менее мы считаем, что ситуация с объёмом поступления ПИИ в регионы РФ сложная. Об этом говорит хотя бы тот факт, что по данным статистики из 13557,5 млрд руб. инвестиций в основной капитал РФ, осуществлённых в 2014 году только 0,6\% (74,6 млрд руб.) пришлось на ПИИ.

С одной стороны, можно говорить о том, что мы «обойдёмся без чужих денег». С другой стоны ряд застойных явлений в экономике регионов, например, в Дальневосточном федеральном округе (ДФО), говорит, о необходимости срочного значительного увеличения инвестиций.

Почему бы не создать действительно льготные условия для иностранных инвесторов на территории ДФО, если отечественные предприниматели не в 
состоянии освоить местные факторы производства. Таким образом, в сфере использования ПИИ как действующего и эффективного инструмента развития отечественной экономики (особенно в приграничных регионах РФ) существуют проблемы «недопонимания скрытых возможностей ПИИ», которые могут быть частично решены разработкой селективно-адресного (не ограничительного) подхода к привлечению и присутствию иностранного каптала на территории России [7].

\section{Сиисок литературы}

1. Бияк Л.Л. Современные подходы к привлечению и регулированию иностранных инвестиций / Л.Л. Бияк, И.В. Кулик, М.А. Кулик // Молодой ученый. - 2016. - №12. - С. 1129-1134 [Электронный ресурс]. - Режим доступа: https://moluch.ru/archive/116/31852/ (дата обращения: 28.05.2018).

2. Инвестиции в России. 2017: Стат. сборник // Росстат. - М., 2017. - 188 с [Электронный pecypc].

Режим доступа: http://www.gks.ru/free_doc/doc_2017/invest.pdf/ (дата обращения: 28.05.2018).

3. Калабеков И.Г. Российские реформы в цифрах и фактах. - Изд. 2, перераб. и доп. - М.: РУСАКИ, 2010. - 498 с.

4. Скрипникова Г.В. Прямые иностранные инвестиции в России: тенденции и проблемы их привлечения / Г.В. Скрипникова, М.С. Постаногова // Науковедение. - 2015. - №4. - С. 1-9 [Электронный ресурс]. - Режим доступа: http://naukovedenie.ru/PDF/106EVN415.pdf/ (дата обращения: 28.05.2018).

5. Статистика внешнего сектора. Прямые инвестиции в Российскую Федерацию. Координированное обследование прямых инвестиций. 2015 г [Электронный ресурс]. - Режим доступа: http:/www.cbr.ru/statistics/?Prtid=svs/ (дата обращения: 28.05.2018).

6. Статистика внешнего сектора. Прямые инвестиции в Российскую Федерацию. Координированное обследование прямых инвестиций. 2016 г [Электронный ресурс]. - Режим доступа: http:/www.cbr.ru/statistics/?Prtid=svs/ (дата обращения: 28.05.2018). 
7. Статистика внешнего сектора. Прямые инвестиции в Российскую Федерацию. Координированное обследование прямых инвестиций. 2017 г [Электронный ресурс]. - Режим доступа: http://www.cbr.ru/statistics/?Prtid=svs/ (дата обращения: 28.05.2018).

\section{References}

1. Biiak, L.L., \& Kulik, I.V. Sovremennye podkhody k privlecheniiu i regulirovaniiu inostrannykh investitsii. Molodoi uchenyi, 2016, 12, 1129-1134. Retrieved from https://moluch.ru/archive/116/31852/

2. (2017). Investitsii v Rossii. 2017: Stat. sbornik. Rosstat. M. Retrieved from http://www.gks.ru/free_doc/doc_2017/invest.pdf/

3. Kalabekov, I.G. (2010). Rossiiskie reformy $\mathrm{v}$ tsifrakh i faktakh., 498. M.: RUSAKI.

4. Skripnikova, G.V. (2015). Priamye inostrannye investitsii v Rossii: tendentsii i problemy ikh privlecheniia. Naukovedenie, 4, 1-9. Retrieved from http://naukovedenie.ru/PDF/106EVN415.pdf/

5. Statistika vneshnego sektora. Priamye investitsii v Rossiiskuiu Federatsiiu. Koordinirovannoe obsledovanie priamykh investitsii. 2015 g. Retrieved from http://www.cbr.ru/statistics/?Prtid=svs/

6. Statistika vneshnego sektora. Priamye investitsii v Rossiiskuiu Federatsiiu. Koordinirovannoe obsledovanie priamykh investitsii. 2016 g. Retrieved from http://www.cbr.ru/statistics/?Prtid=svs/

7. Statistika vneshnego sektora. Priamye investitsii v Rossiiskuiu Federatsiiu. Koordinirovannoe obsledovanie priamykh investitsii. 2017 g. Retrieved from http://www.cbr.ru/statistics/?Prtid=svs/

Рашев Роман Олегович -магистрант ФГАОУ ВО «Тюменский государственный университет», Россия, Тюмень.

Rashev Roman Olegovich - graduate student at the Tyumen State University, Russia, Tyumen. 